\author{
M.Koniusz, dr \\ Wyższa Szkoła Ekonomiczno-Humanistyczna \\ Bielsko Biała, Polska
}

\title{
WPLYW KOMUNIKACJI NA REALIZACJĘ CELÓW ORGANIZACJI PUBLICZNEJ
}

Pracownicy sa najcenniejszym zasobem każdej organizacji bez względu na to czy jest to organizacja publiczna czy prywatna. Skuteczne funkcjonowanie organizacji zależy od bardzo wielu czynników, ale kluczowa rolę odgrywa czynnik ludzki. To ludzie tworza organizację $i$ w ogromnym stopniu decyduja o jej sukcesie. Aby organizacja funkcjonowała w skuteczny sposób, nie wystarczy sama obecność pracowników. Istotę stanowi łączność pomiędzy członkami załogi, umiejętność porozumiewania się oraz zdolność odbioru $i$ rozumienia tego, co maja oni sobie do przekazania wykonujac obowiazki zawodowe. Równie ważne dla skuteczności funkcjonowania organizacji sa jej relacje z otoczeniem. Od wypracowania właściwych relacji z klientami, kontrahentami, bankami itp., zależy czy organizacja odniesie sukces, czy zostanie skazana na porażkę. Celem artykułu jest próba poznania procesu komunikowania się $w$ organizacji publicznej na przykładzie Poczty Polskiej oraz pokazanie zależności pomiędzy stosowanymi formami wymiany informacji a sprawnościa funkcjonowania organizacji, przedstawienie głównych form komunikowania się nie tylko między pracownikami na różnych szczeblach, ale również dialogu pracownik - klient oraz ukazanie procesu komunikacyjnego, który wpływa nie tylko na pracowników danej jednostki organizacyjnej, ale także na klientów.

Slowa kluczowe: komunikacja; organizacje społeczne; cele społeczne organizacji.

Wstęp. Komunikacja stanowi podstawę stosunków międzyludzkich, gdyż to na niej opierają się wszystkie procesy zachodzące zarówno w życiu prywatnym, jak i zawodowym. Nadrzędnym celem każdej organizacji jest realizowanie potrzeb klientów. Na organizacjach publicznych, których podstawową misją jest zaspokajanie potrzeb obywateli spoczywa duża odpowiedzialność. Bez prawidłowej komunikacji zarówno tej wewnętrznej jak i zewnętrznej żadna organizacja publiczna nie może funkcjonować w sposób zadowalający. Ważne jest, aby osoby kierujące organizacjami publicznymi zdawały sobie sprawę ze znaczącego wpływu komunikacji na rozwój i sprawne funkcjonowanie organizacji.

Analizę wpływu komunikacji na realizację celów organizacji publicznej przeprowadzono na przykładzie wybranego Urzędu Poczty Polskiej w Krakowie. Celem jest ukazanie zależności między komunikacją a sprawnym działaniem organizacji publicznej oraz barier, które utrudniają prawidłowy przebieg procesu komunikowania się, jak i propozycji działań mogących usprawnić funkcjonowanie organizacji w tym zakresie.

1.Specyfika funkcjonowania organizacji publicznych

„Organizacja publiczna posiada te same cechy, które posiadają inne organizacje. Jednak to, co określa specyfikę organizacji publicznych to publiczność organizacji. Ma to swoje odzwierciedlenie w wartościach, celach i relacjach z otoczeniem oraz strukturze w organizacji publicznej”.

Społeczno-ekonomiczny system, którego podsystemy celów i wartości, psychospołeczny, materialnotechniczny oraz podsystem struktury, a przede wszystkim podsystem zarządzania oraz relacje ze środowiskiem zewnętrznym wyróżniają się publicznością jako immanentną cechą, odróżniającą ją od innych typów organizacji. ${ }^{1}$ Cele instytucji publicznej biorą się z publiczności organizacji. Cele te należy rozpatrywać w trzech kategoriach:

1. różnorodności celów organizacji publicznych, instytucje publiczne chcąc zaspokajać potrzeby obywateli realizują liczne, często bardzo odmienne cele, formułowane przez wiele grup interesariuszy,

2. niejednoznaczności celów, ich wielowymiarowy charakter powoduje, że menedżerowie skupiają się na wielu obszarach jednocześnie, co prowadzi do powstania konfliktów, a zadaniem menedżerów jest rozwiązywanie występujących konfliktów oraz równoważenie wpływów poszczególnych grup interesariuszy,

3. wyróżniającym się charakterze wyznaczonych celów, są nimi na przykład sprawiedliwość bądź publiczna odpowiedzialność przed obywatelem. ${ }^{2}$

W organizacjach publicznych występuje mniejsza autonomia menadżerów, niż w organizacjach prywatnych. Są one bardziej sformalizowane, a problemy są rozwiązywane w sposób charakterystyczny dla modelu biurokratycznego. ${ }^{3}$

Publiczność organizacyjna wpływa bezpośrednio na relacje placówek publicznych z otoczeniem oraz funkcjonowanie i działanie organizacji publicznych. Relacje te charakteryzują się one przede wszystkim:

\footnotetext{
${ }^{1}$ Kożuch B., Zarzadzanie publiczne w teorii i praktyce polskich organizacji, Warszawa 2004, s.96

2 Ibidem, s.92

3 Ibidem, ss. 93-94
} 
- małą presją ze strony konkurencji. ( $\mathrm{z}$ racji zajmowania najczęściej dominującej pozycji na rynku wytwarzanych dóbr i usług),

- dużą otwartością na wpływy otoczenia zewnętrznego ( pozwala to dostosować działalność instytucji do ciągle zmieniających się potrzeb publicznych),

- funkcjonowaniem instytucji w zmiennym otoczeniu ( wynikającym na przykład z ich powiązań z polityką, w przypadku której planowanie długookresowe jest rzadkością),

- dużą złożonością interakcji organizacji z ich środowiskiem zewnętrznym ( spowodowaną w głównej mierze tym, iż odbiorcami dóbr oraz usług publicznych mogą być różnorodne grupy interesariuszy). ${ }^{4}$

Aby dokładniej zrozumieć specyficzny styl funkcjonowania organizacji publicznych warto zwrócić uwagę na ich otoczenie. Obok podmiotów, mających bezpośredni wpływ na organizację istnieją czynniki, na które organizacja ma pewien wpływ. Obie te grupy tworzą wspólne otoczenie celowe, zwane także bezpośrednim albo zadaniowym. Uczestnicy tego typu otoczenia nazwani zostali interesariuszami zewnętrznymi, gdyż to na nich ma największy wpływ opisywana grupa organizacyjna. Intersariusze zewnętrzni to obywatele, podatnicy, a także dostawcy, konkurenci, usługobiorcy i różnego rodzaju instytucje państwowe czy samorządowe. Interesariuszami wewnętrznymi, natomiast, mogą być osoby lub grupy osób, które należą do środowiska wewnętrznego. Są to np. akcjonariusze, kierownictwo, także grupa nadzorcza. ${ }^{5}$

Interesariusze w organizacjach publicznych są grupami dość licznymi i w znaczący sposób wpływają na nie. Zarządzając organizacją publiczną należy bezwzględnie wziąć pod uwagę duże zróżnicowanie tej grupy, jej interesy, (często sprzeczne), a także możliwość stosowania różnorodnych form wzajemnych relacji. ${ }^{6}$ Menedżerowie organizacji publicznych podejmując decyzję powinni brać pod uwagę interesy każdej zainteresowanej strony.

Obok otoczenia celowego istnieje również otoczenie ogólne. Jest nim „zespół szerokich wymiarów i sił, wśród których działa organizacja, a które tworzy ogólny kontekst dla tych działań”7

Wymiary te rozpatrywane być mogą $\mathrm{w}$ aspektach:

- technologicznym (dostępne metody przekształcania zasobów w usługi lub produkty),

1. ekonomicznym (ogólna sytuacja gospodarcza systemu, w którym działa organizacja),

2. prawno-politycznym (uregulowania prawne i stosunki państwa do innych organizacji),

- międzynarodowym (wpływ na organizacje warunków panujących w innych krajach),

- socjokulturowym (powszechne wartości, obyczaje, cechy społeczeństwa). ${ }^{8}$

Otoczenie ogólne ma wpływ na działalność każdej organizacji publicznej, nieprzerwanie realizującej swoje zadania i cele.

Do organizacji publicznych zaliczane są jednostki administracji publicznej. Administracja publiczna to: „zespół działań, publicznego przez różne podmioty, organy i instytucje, na podstawie ustawy i w określonych prawem formach czynności i przedsięwzięć organizatorskich i wykonawczych, prowadzonych na rzecz realizacji interesu". ${ }^{9}$ Definicja ta zwraca uwagę na pojęcie interesu publicznego czyli dobra wspólnego.

Instytucje administracji publicznej realizują misję z zakresu :

1. administracji jako właściciela majątku (zarządzanie majątkiem publicznym ),

2. administracji świadczącej (realizacja usług publicznych),

3. administracji porządkowo-reglementacyjnej,

4. zarządzania rozwojem (działania planistyczne oraz koordynacyjne). ${ }^{10}$

Złożoność celów organizacji wynika $\mathrm{z}$ założeń do jakich została powołana. W celu prawidłowego funkcjonowania organizacji winna ona utrzymywać dobre relacje $z$ otoczeniem. Podstawą takich relacji jest sprawne, rzetelne i zrozumiałe informowanie na każdej płaszczyźnie nie tylko swoich klientów, ale też pracowników. Aby tego dokonać należy zrozumieć samą istotę i znaczenie komunikacji.

2. Istota procesów komunikacyjnych

Przez procesy komunikacyjne ludzie oddziaływują na siebie, zdobywają wiedzę, a także przejmują pewne wzorce zachowań. Ich uczestnictwo w procesie komunikowania jednoznacznie świadczy o społecznym charakterze tego procesu. Komunikacja społeczna jest pojęciem ogólnym, zawierającym wszystkie poziomy komunikowania: grupowe, instytucjonalne, masowe, oraz te najmniej złożone - komunikowanie interpersonalne.

Proces komunikowania jest procesem złożonym, który cechuje różnorodność. Składa się on ze sformalizowanych określonych części. W literaturze występuje podział procesu komunikowania na kilka

\footnotetext{
4 Ibidem, s.95

${ }^{5}$ Plawgo B., Szpak A., Radziwon P., Zarzadzanie relacjami organizacji publicznych z ich otoczeniem /w:/ Kożuch B. (red.), Problemy zarządzania organizacjami publicznymi, Kraków 2006, s.75

${ }^{6}$ Ibidem, s.80

${ }^{7}$ Griffin R.W., Podstawy zarzadzania organizacjami, Wyd. Naukowe PWN, Warszawa 2004 s.76

${ }^{8}$ Kożuch B., Kożuch A., Plawgo B., Podstawy zarządzania organizacjami, wyd.FWZ, Kraków 2005, s.24

${ }^{9}$ Izdebski M., Kulesza M., Administracja publiczna - zagadnienia ogólne, wyd.Liber, Warszawa 2004, s.96

${ }^{10}$ Ibidem, s.104
} 
elementów, które stanowią: uczestnicy, komunikat, kanał, szumy i sprzężenie zwrotne. ${ }^{11}$ Elementy te występują w każdym procesie komunikowania, wiążąc się ze sobą i decydując o rodzaju i charakterze całego procesu, którego inicjatorem jest nadawca (instytucja, grupa, bądź jednostka). Nadawca chce, aby komunikat został zrozumiany i prawidłowo zinterpretowany. Jeśli komunikat ma takie samo znaczenie zarówno dla nadawcy jak i dla odbiorcy, należy stwierdzić, iż zaistniał proces doskonałej komunikacji społecznej. Problemy w komunikacji pojawiają się, gdy przekaz zapoczątkowany przez nadawcę został zniekształcony lub podany w sposób niezrozumiały, przez co źle odczytany przez odbiorcę. Dodatkową przeszkodą może być fakt, że każdy indywidualnie odbiera i interpretuje przekazywane informacje. Wynika to ze zróżnicowania ludzkiej natury, doświadczeń życiowych, sposobu wychowania, wpojonych idei, kultur, wiary itp. Nadawca powinien przekazać treść komunikatu używając właściwych środków ekspresji i symboli, tak, aby została ona zrozumiana zgodnie z jego oczekiwaniami. Nie bez znaczenia pozostają również wzajemne relacje pomiędzy uczestnikami procesu komunikacji. Łatwiej bowiem o porozumienie pomiędzy uczestnikami o zbliżonych poglądach niż z osobami pozostającymi w konflikcie, reprezentującymi odmienne interesy i dążącymi do wygranej, starając się wyeliminować przeciwnika.

Nadawca komunikatu chcący przekazać odbiorcy jego treść używa do tego celu symboli przez co koduje swoją wypowiedź. Symbole stanowią nie tylko wypowiedziane i napisane słowa, al także sygnały niewerbalne, które decydują o tym czy odbiorca prawidłowo odczyta wiadomość, a jego reakcja okaże się prawidłowa $\mathrm{z}$ punktu widzenia nadawcy. Adresat, po otrzymaniu informacji w formie symboli, zmienia komunikat w treść, dokonuje więc dekodowania, po czym odczytuje otrzymaną informację.

Proces komunikacji jest możliwy tylko wtedy jeśli zostanie wybrany odpowiedni kanał komunikacji, czyli nastąpi prawidłowy wybór przekazu. Kanał to sposób przekazania informacji, w którym, uczestniczą ludzkie zmysły. Podczas bezpośredniego kontaktu nadawcy z adresatem, komunikowanie jest wielokanałowe, gdyż w trakcie przekazywania informacji mogą brać udział wszystkie zmysły.

Ten rodzaj komunikowania umożliwia natychmiastową reakcję odbiorcy czyli sprzężenie zwrotne natychmiastowe. W trakcie bezpośredniej komunikacji, jej uczestnicy zazwyczaj zamieniają się rolami, tzn. odbiorca staje się nadawcą i odwrotnie. Nazywa się to komunikacją dwukierunkową.

Podczas komunikacji pośredniej wykorzystywane są tylko dwa zmysły: wzrok i słuch. Komunikację pośrednią wykorzystuje się wtedy, gdy nadawca nie ma możliwości bezpośredniego kontaktu z odbiorcą. Jednak w tego rodzaju procesie komunikacji nie można od razu poznać reakcji odbiorcy na przekaz, a więc sprzężenie zwrotne nie działa natychmiast, lecz z pewnym opóźnieniem. Sprzężenie zwrotne jest kolejnym, bardzo istotnym elementem procesu komunikowania, informującym o tym, czy cel komunikatu został osiągnięty. Odbiorca w sposób pisemny lub ustny potwierdza fakt odebrania przekazu, oraz stopień jego akceptacji i zrozumienia. Zrozumienie treści komunikatu może wyrażać się poprzez prawidłowe wykonanie zadania lub polecenia. Przy przekazywaniu informacji, założony cel nie zawsze może być osiągnięty z powodu zakłóceń, tzw. szumów komunikacyjnych. Zakłócenia te mogą być zarówno zewnętrzne ( np. dzwoniący telefon $)^{12}$ jak i wewnętrzne ( np. złość, zmęczenie, ból ). Dodatkową kategorię zakłóceń stanowią tzw. zakłócenia semantyczne, czyli takie, które związane są z na przykład doborem niezrozumiałego słownictwa, co może spowodować niewłaściwą interpretację komunikatu przez odbiorcę.

Mimo więc tego, iż proces porozumiewania się jest na stałe wpisany w nasze życie i wydaje się on procesem łatwym, oczywistym i prostym, to w rzeczywistości komunikowanie się jest bardzo skomplikowane i złożone. Według B. Sobkowiak rozróżniać należy formy komunikowania w zależności od:

5. sposobu przekazywania informacji,

6. rodzaju relacji między uczestnikami procesu. ${ }^{13}$

Komunikacja werbalna używa do przekazu informacji języka pisanego i mówionego. Ważne jest również zastosowanie dźwięków i symboliki słów, po to aby wypowiedź nabrała dynamiki i była dobrze zrozumiana. W celu zapewnienia dobrej relacji $\mathrm{z}$ odbiorcą, ważne jest zapoznanie się z normami kulturowymi w danej organizacji i stosowanie się do nich, gdyż są one niezbędnym warunkiem skutecznego przekonywania i komunikowania się. Wśród podstawowych form komunikowani rozróżnić należy:

1. bezpośrednią, gdy rozmówcy mają ze sobą kontakt osobisty, mogą przekazywać sobie informację na bieżąco, a także obserwować swoje reakcje,

2. pośrednią, gdy nie jest możliwy kontakt osobisty, tego typu komunikacja wykorzystywana jest np. w przekazie internetowym, czy telefonicznym,

3. jednokierunkową, gdy nadawca przekazuje pewne treści jako stwierdzenie faktu i nie oczekuje od odbiorcy żadnej odpowiedzi,

\footnotetext{
${ }^{11}$ Listwan T., Zarzadzanie kadrami, wyd. C.H. Beck, Warszawa 2004, s.287

${ }^{12}$ Ibidem s. 288

${ }^{13}$ Sobkowiak B., Wspótczesne systemy komunikowania, Wydawnictwo Uniwersytetu Wrocławskiego, Wrocław 1998, s.15
} 
Tabela 1

Formy komunikacji

\begin{tabular}{|l|l|l|}
\hline \multirow{2}{*}{ Kryterium } & \multicolumn{2}{|c|}{ Formy komunikowania } \\
\hline \multirow{4}{*}{ Sposób przekazywania komunikatu } & Werbalna & niewerbalna \\
\cline { 2 - 3 } & Ustna & pisemna \\
\cline { 2 - 3 } & Bezpośrednia & pośrednia \\
\hline \multirow{5}{*}{ Rodzaj relacji między uczestnikami procesu } & Jednokierunkowa & dwukierunkowa \\
\cline { 2 - 3 } & Symetryczna & niesymetryczna \\
\cline { 2 - 3 } & Formalna & nieformalna \\
\cline { 2 - 3 } & Obronna & podtrzymująca \\
\hline
\end{tabular}

Źródło : Opracowanie na podstawie: B. Sobkowiak, Współczesne systemy komunikowania, /w:/ Dobek - Ostrowska B. (red.) Wydawnictwo Uniwersytetu Wrocławskiego, Wrocław 1998, s. 15

3. dwukierunkową, gdy nadawca wypowiada komunikat i oczekuje na reakcję adresata, na treść jego komunikatu,

4. symetryczną, gdy zarówno odbiorca jak i nadawca posiadają ten sam status społeczny, bądź znajdują się na takim samym szczeblu hierarchii organizacyjnej,

5. niesymetryczną, gdy jeden z rozmówców występuje z pozycji ,wyższej”, wtedy komunikowanie się jest bardziej oficjalne,

6. formalną, gdy dokładnie sprecyzowano sposób, w jaki ludzie mają się komunikować ze sobą,

7. nieformalną, gdy ludzie komunikują się ze sobą w sposób swobodny, spontaniczny i nieskrępowany żadnymi uregulowaniami.

Sukces procesu komunikacyjnego zależy od nadawcy. Sposób, w jaki zostanie przekazana informacja, może wywołać u adresata reakcję obronną albo podtrzymującą . Reakcja podtrzymująca zdecydowanie zwiększa szanse na prawidłowe porozumienie się rozmówców. Natomiast reakcja obronna może doprowadzić do tego, że porozumienie nie dojdzie do skutku.

Style komunikacyjne to nic innego, jak różnorodne postawy i zachowania podmiotów w trakcie rozmowy. Podmioty te mogą na siebie oddziaływać w zależności od kontekstu i intencji procesu komunikacji. Ową różnorodność widać w sposobie prowadzenia rozmowy, reagowania na otrzymane informacje, argumenty przekazywane przez uczestników rozmowy itp. J. Stankiewicz wyróżnia cztery podstawowe style komunikacyjne $\mathrm{w}$ organizacjach: przyjacielski, doradczy, analityczny i wodzowski. ${ }^{14}$

W zależności od okoliczności, treści przekazu oraz osób, z którymi wchodzi się w relacje można stosować kilka stylów komunikacyjnych. Wybór stylu zależy od kilku czynników takich jak osobowość, kultura, w jakiej zostaliśmy wychowani, nabyte doświadczenie, wartości zaczerpnięte z dzieciństwa, status społeczny, który w trakcie procesu komunikacyjnego pozwala na występowanie z pozycji odgórnej, dając możliwość dyktowania warunków lub z pozycji dostosowania i przyjęcia racji rozmówców postawionych wyżej w hierarchii.

Bardzo istotną rolę pełni również sama informacja. Jest oczywiste, że treści pozytywne wywołują inne reakcje od treści negatywnych i znacząco wpływają na wybór stylu komunikacji.

Komunikacja jest procesem złożonym i wymaga starań zarówno ze strony nadawcy jak i odbiorcy. Ważne jest więc rozumienie procesu komunikacji niezbędne w realizacji celów.

3. Komunikacja jako narzędzie sprawnego działania organizacji publicznych

Proces komunikowania odgrywa bardzo istotną rolę i spełnia wiele funkcji. Podstawową rolą jest tworzenie więzi i poprawnych kontaktów, przez co wpływać można na zachowania innych i egzekwować pewne wartości i normy. Pomaga to lepiej zrozumieć otaczający świat i co najważniejsze, innych ludzi. Omawiając kwestię usprawniania przebiegu komunikacji w organizacji publicznej, należy wspomnieć o jej roli w procesie zarządzania.

Tabela 2

Style komunikacyjne w organizacji

\begin{tabular}{|l|l|}
\hline \multicolumn{1}{|c|}{ Styl komunikacyjny } & \multicolumn{1}{c|}{ Charakterystyka } \\
\hline przyjacielski & dążenie do podtrzymania dobrych relacji z innymi \\
\hline doradczy & aktywność i dążenie do wdrożenia w życie swoich racji \\
\hline analityczny & współpraca i prawidłowa realizacja zadań \\
\hline wodzowski & dominacja w grupie, skłonność do wywierania presji, narzucanie swoich racji \\
\hline Źródło: opracowanie na podstawie : Stankiewicz J., komunikowanie się w organizacji, wyd. Astrum, Wrocław 1999, s.38
\end{tabular}

\footnotetext{
${ }^{14}$ Stankiewicz J., Komunikowanie się w organizacji, wyd. Astrum, Wrocław 1999, s.38
} 
Komunikowanie służy do przekazywania informacji pomiędzy pracownikami znajdującymi się na różnych szczeblach hierarchii, czyli pełni rolę informacyjną. Gromadzone w procesie komunikacji informacje ułatwiają kierownictwu podejmowanie decyzji, stąd rola decyzyjna. Kolejna rola wiąże się z możliwością wielokierunkowego porozumiewania się wszystkich osób w jakiś sposób związanych $\mathrm{z}$ organizacją: przełożonych, podwładnych, kontrahentów czy klientów. ${ }^{15}$ Istota wymienionych ról sprowadza się do efektywności przebiegu procesów komunikacyjnych, do skuteczności przekazywania i odbioru komunikatów przepływających pomiędzy członkami załogi, oraz wszystkimi osobami pozostającymi w związku z organizacją. Usprawnianie przebiegu komunikacji to podejmowanie próby wypracowania płynności w porozumiewaniu i eliminowanie barier komunikacyjnych. Niezbędne jest ciągłe kształtowanie wysokiego poziomu świadomości wszystkich pracowników, stałe pogłębianie ich wiedzy z zakresu komunikacji interpersonalnej i zgłębianie przez nich istoty poszczególnych elementów procesu komunikowania. Warto przeanalizować sposób porozumiewania się biorąc pod uwagę każdy element procesu komunikacyjnego. Od umiejętności przekonywania zarówno pracowników jak i klientów uzależniony jest poziom jakości usług, oraz kształtowanie wizerunku organizacji.

W procesie komunikacyjnym ważny jest sposób przekazywania informacji, zarówno tych pierwotnych, płynących od nadawcy, jak i informacji zwrotnych, które pozwalają ocenić, czy przekazywane komunikaty zostały prawidłowo zinterpretowane i czy ich odbiór przełożył się na właściwe działanie pracowników. Każda organizacja powinna dążyć do wypracowania takich sposobów przekazywania komunikatów, aby obieg informacji przebiegał sprawnie i był efektywny, aby członkowie organizacji potrafili dochodzić do porozumienia i wspólnie tworzyć najlepsze dla przedsiębiorstwa rozwiązania, równocześnie dając satysfakcję klientom. Należy dążyć, aby informacje dostarczane kierownictwu dla celów decyzyjnych były pełne i wiarygodne, pozwalające na unikanie błędów w podejmowaniu decyzji.

Jeśli osoba sprawująca funkcję kierowniczą w sposób apodyktyczny, nie znoszący sprzeciwu, wydaje polecenia, pracownicy nie czują się współodpowiedzialni, w rezultacie, komunikowanie nie tylko staje się nieskuteczne, ale można również spodziewać się narastania konfliktów. Jeśli natomiast pracownicy mają możliwość wyrażenia swojego zdania, partycypowania w budowaniu wspólnych wartości, czują się potrzebni i bardziej angażują się w pełnione przez siebie obowiązki.

Umiejętności komunikacyjne stanowią podstawę w negocjacjach z klientami. Istotne znaczenie można tu przypisać znajomości technik perswazyjnych, oraz postępowania w myśl filozofii: każdy wygrywa, która według Kevina Hogana jest sposobem na życie. ${ }^{16}$ Zarówno w życiu prywatnym jak i w kontaktach zawodowych,

wygrywa ten, kto potrafi dostrzec potrzeby drugiego człowieka i postępować tak, aby potrzeby te w miarę możliwości zostały spełnione. Nie chodzi tu jednak o bezgraniczne podporządkowanie się innym, lecz o dążenie do budowania relacji opartych na zaufaniu, dających satysfakcję obu stronom. Warto ustąpić dziś, po to, aby w przyszłości ustępstwo to zaowocowało po wielokroć. Osoba, która w dążeniu do spełnienia swoich oczekiwań równocześnie wykazuje się wrażliwością na potrzeby innych, potrafi dostrzec odpowiedni moment do przekazania każdej treści, nie raniąc uczuć drugiego człowieka i doprowadzić do sytuacji, w której obie strony będą usatysfakcjonowane. ${ }^{17}$

Oprócz sposobu przekazywania poleceń, czy organizacji zadań, istotny jest również sposób informowania załogi o efektach pracy, oraz forma przekazywania ocen. ${ }^{18}$ Zarówno pozytywna ocena jak uwagi krytyczne, w zależności od sposobu ich komunikowania, mogą wywoływać różne reakcje u pracowników, motywując lub demotywując ich do dalszych działań. Bardzo istotny staje się właściwy dobór słów i przedstawienie uwag w sposób konkretny i rzeczowy, językiem zrozumiałym dla odbiorcy. Przekazywanie krytycznych uwag w taki sposób, aby nie zniechęcać pracownika do wykonywania zleconych mu zadań stanowi bardzo ważną umiejętność, wyzwalającą dobre reakcje i mobilizującą pracowników. Umiejętność ta niweluje również konflikty, usprawniając tym samym procesy komunikacyjne w organizacji. W zarządzaniu należy wziąć pod uwagę różnorodność i indywidualizm ludzkich osobowości. Kierujący zespołem powinien charakteryzować się empatią, posiadać wiedzę z zakresu psychologii, oraz umiejętność praktycznego wykorzystywania tej wiedzy w zarządzaniu ludźmi. Aby zmobilizować zespół do efektywnego działania, należy zastosować motywujące środki działania. Indywidualne podejście do każdego pracownika, choć wymaga sporego wysiłku ze strony przełożonego, może w przyszłości zaowocować nie tylko dobrymi relacjami międzyludzkimi, ale również przynosić korzyści całej organizacji. Warto tu wspomnieć o znaczeniu czynników związanych ze sposobem wypowiadania się i budowania relacji interpersonalnych, nazywanych regułami konwersacyjnymi. ${ }^{19}$

Reguły te mówią o czytelności wypowiedzi, o dążeniu do przekazywaniu sedna, bez zbędnych ubarwień, nadczytelności i nadmiaru treści. Ponadto podkreślają one wagę okazywania szacunku swojemu rozmówcy, przejawiającego się podejmowaniem próby wczuwania się w jego rolę, spojrzenia na problemy z jego punktu widzenia. Osoba stosująca reguły konwersacyjne $w$ relacjach międzyludzkich, potrafi jasno i otwarcie przedstawiać swoje zdanie, bez obrażania uczuć innych osób, będąc również dobrym słuchaczem, który nigdy nie lekceważy opinii swoich rozmówców.

\footnotetext{
${ }^{15}$ Piasecki B. (red.), Ekonomika i zarzadzanie mała firma, wyd. PWN, Łódź 2001, s.225

${ }^{16}$ Hogan K., Psychologia perswazji. Strategie i techniki wywierania wptywu na ludzi, wyd. Jacek Santorski \& Co, Warszawa 2001, s. 12

${ }^{17}$ Ibidem, s.248

${ }^{18}$ Stankiewicz J., Komunikowanie ... op.cit., s.159

${ }^{19}$ Ibidem, ss. 159-160
} 
Będąc nadawcą komunikatów, kierujący organizacją powinien zadbać o spójność przekazywanych słownie treści z komunikatami o charakterze niewerbalnym, co w znacznym stopniu podnosi wiarygodność i wzbudza zaufanie odbiorców. W wyrażaniu swoich opinii i sugestii powinien być obiektywny, nie sugerować się stereotypami czy uprzedzeniami. Tylko taka postawa pozwala na budowanie właściwych relacji z podwładnymi, oraz własnego autorytetu. Osoba wypowiadająca się w sposób jasny i otwarty, bez stosowania manipulacji, ma duże szanse na unikanie barier komunikacyjnych, a tym samym na usprawnienie przebiegu procesów komunikacyjnych w organizacji.

Jako odbiorca komunikatów, kierujący musi stać się dobrym słuchaczem, z uwagą i szacunkiem traktować nadawców, utwierdzając w nich poczucie własnej wartości, dając im pewność, że są kimś ważnym dla organizacji. Nie można mówić o skutecznym komunikowaniu w organizacji, jeżeli nie występuje w nim szybka reakcja na przekazywane informacje, czyli sprzężenie zwrotne. Jakość informacji uzyskiwana od odbiorców komunikatu, będących reakcją na pierwotny przekaz, decyduje o skuteczności procesu komunikacji. W zależności od sposobu, w jaki informacja zwrotna wpływa do nadawcy, na ile jest ona szczegółowa i konkretna, cały proces komunikacyjny można uznać za bardziej lub mniej skuteczny. ${ }^{20}$ Kierownictwo organizacji potrafiące odrzucić stereotypy $\mathrm{i}$ uprzedzenia, nie zawyżające kompetencji językowych $\mathrm{w}$ porozumiewaniu się z podwładnymi $\mathrm{i}$ klientami, podnosi szanse na efektywność komunikacji, prawidłową interpretację przekazywanych treści i sukcesy negocjacyjne. Osoby kierujące organizacją stają się dla wielu osób w niej zatrudnionych autorytetami, osobami, od których przejmują wzorce zachowań, starając się naśladować ich sposób postępowania. Jeśli więc są to dobre wzorce, powszechne ich stosowanie wpłynie korzystnie na całą organizację, przyczyni się do umacniania więzi, oraz zwiększania poziomu satysfakcji zawodowej zatrudnionych w niej osób.

4. Analiza procesu komunikacji w badanej organizacji

W roku 1928 utworzono Państwowe Przedsiębiorstwo „Polska Poczta, Telegraf i Telefon” (PPTiT), które wydzielano z ogólnej administracji państwowej. Pozwoliło to na usprawnienie gospodarki i podniesienie rentowności tej branży. Wybuch II Wojny Światowej przerwał realizację programu modernizacji Poczty, a cały dorobek dwudziestolecia międzywojennego w dziedzinie nowoczesnej komunikacji został zniszczony i rozproszony. Okres powojenny, to przede wszystkim tworzenie sieci pocztowo-telekomunikacyjnej, uruchamianie placówek pocztowych i tworzenie dyrekcji okręgów. Obwodowe urzędy pocztowotelekomunikacyjne zasięgiem swojego działania obejmowały obszar jednego lub kilku powiatów lub wydzielonych dzielnic miast. Pełniły one podwójną funkcję: funkcję jednostki zarządzającej, nadzorującej i kontrolującej działalność podległych jednostek organizacyjnych znajdujących się na obszarze ich działania oraz funkcję jednostki eksploatacyjnej.

Podstawowym zadaniem Urzędów Pocztowych jest zagwarantowanie dostępu obywatela do usług pocztowych oraz terminowe dostarczanie przesyłek pocztowych. Przyjmując obowiązujące w Unii Europejskiej normy Poczta Polska z dniem 1 lipca 2002 roku wdrożyła nowe standardy doręczania przesyłek listowych w obrocie zagranicznym i krajowym. Przesyłki listowe zostały podzielone na szybkość dostarczenia przesyłek, a nie jak to było wcześniej zawartość. Podział ten został utworzony w celu możliwości wyboru świadczonych usług. ${ }^{21}$

Zasady działania jednostek organizacyjnych Poczty Polskiej określa Regulamin Organizacyjny z dnia 04.10.2005 roku wprowadzony Zarządzeniem nr 142 Dyrektora Generalnego Poczty Polskiej. Określa on strukturę organizacyjną, wewnętrzną organizację oraz zadania utworzonych jednostek organizacyjnych.

Do jednostek organizacyjnych zajmujących się bezpośrednio sprzedażą usług pocztowych, należy obsługujące klientów masowych Centrum Usług Pocztowych oraz, Centrum Sieci Pocztowej, która od 01. kwietnia 2008 roku Zarządzeniem Dyrektora Generalnego połączyła się w jedną całość i istnieje pod nazwą Centrum Poczty.

Sieć Urzędów Pocztowych stanowi kwintesencję działalności Poczty Polskiej. Podlegają one organizacyjnie Dyrektorowi Oddziału Rejonowego i to właśnie na tym poziomie kształtuje się wizerunek Poczty Polskiej. Pracownicy zatrudnieni w Urzędach Pocztowych jako osoby mające bezpośredni kontakt z klientem tworzą w jego oczach obraz całego przedsiębiorstwa.

Poczta Polska, jest zaraz po PKP jedną z największych firm w Polsce. Zatrudnia blisko 100 tysięcy osób i ma w całym kraju ogromną sieć ponad 8,2 tysiąca placówek świadczących kilkaset rodzajów usług. Jest ona firmą o szerokim wachlarzu usług, dających możliwość do silnej konkurencji z firmami o podobnym profilu usług.

5. Formy komunikacji w badanej organizacji

Poczta Polska stosuje dwa rodzaje komunikacji: formalną i nieformalną. Komunikacja formalna to określone odgórnie przez Dyrekcję drogi komunikacyjne, którymi płyną informacje. Z racji wielkości zatrudnienia w Poczcie Polskiej są to komunikaty i rozporządzenia w formie pisemnej, przekazywane najczęściej przez naczelnika Urzędu Pocztowego, bądź kierownika danej sekcji lub kierownika zmiany. Do komunikacji formalnej zalicza się również tygodnik pracowników Poczty zatytułowany „Poczta Polska”, w której zamieszczane są nowelizacje ustaw, komunikaty, aktualności jak również informacje dotyczące codziennej działalności organizacji.

\footnotetext{
${ }^{20}$ Stankiewicz J., Komunikowanie.... op.cit. s.158

${ }^{21} \mathrm{http}: / /$ www.poczta-polska.pl/historia
} 
Poczta Polska posiada też wewnętrzną stronę internetową (intranet), z której korzystać można tylko z komputera firmowego. Dysponuje też specjalnym programem „Lotus” stworzonym w celu ulepszenia komunikacji między pracownikami w różnych Urzędach Pocztowych. Ma on usprawnić komunikację, jak również skrócić czas oczekiwania na odpowiedź. Program ten objęty jest ścisłą tajemnicą i Poczta niechętnie o nim „mówi”, gdyż to jego drogą przesyłane są rozporządzenia, nowe strategie firmy i polecenia odgórne.

Komunikacja nieformalna to informacje płynące spontanicznie, bez ograniczeń.

W zespołach pracowniczych (zadaniowych) będących wyodrębnionymi cząstkami całej organizacji, ich członkowie ustanowili własne normy, których przestrzeganie stało się obowiązujące, choć jest prawem niepisanym. Komunikowanie opiera się tu przede wszystkim na ustnym przekazywaniu informacji. Taki sposób porozumiewania się umożliwia bezpośredni kontakt z przełożonym, dzielenie się z nim sugestiami dotyczącymi wykonywanych zadań, pomysłami i wnioskami. Komunikacja nieformalna Urzędu Pocztowego z innymi Urzędami Pocztowymi to przede wszystkim rozmowy telefoniczne.

W celu zbadania systemu komunikowania się w Urzędzie Pocztowym przeprowadzone zostało badanie kwestionariuszowe w jednym z Urzędów Pocztowych Krakowa. Kwestionariusz ankietowy został wypełniony przez pracowników tego Urzędu oraz losowo wybranych klientów, korzystających z usług badanej organizacji. Na pytanie dotyczące oceny stopnia komunikatywności pracowników Urzędu z klientami ponad $7 \%$ spośród ankietowanych twierdzi, że jest na bardzo niskim poziomie ( w skali od 1 do 5 - była to ocena 1). Należy jednak podkreślić fakt, że ponad 1/3 klientów wyraża opinię, że komunikatywność pracowników Urzędu Pocztowego jest wysoka.

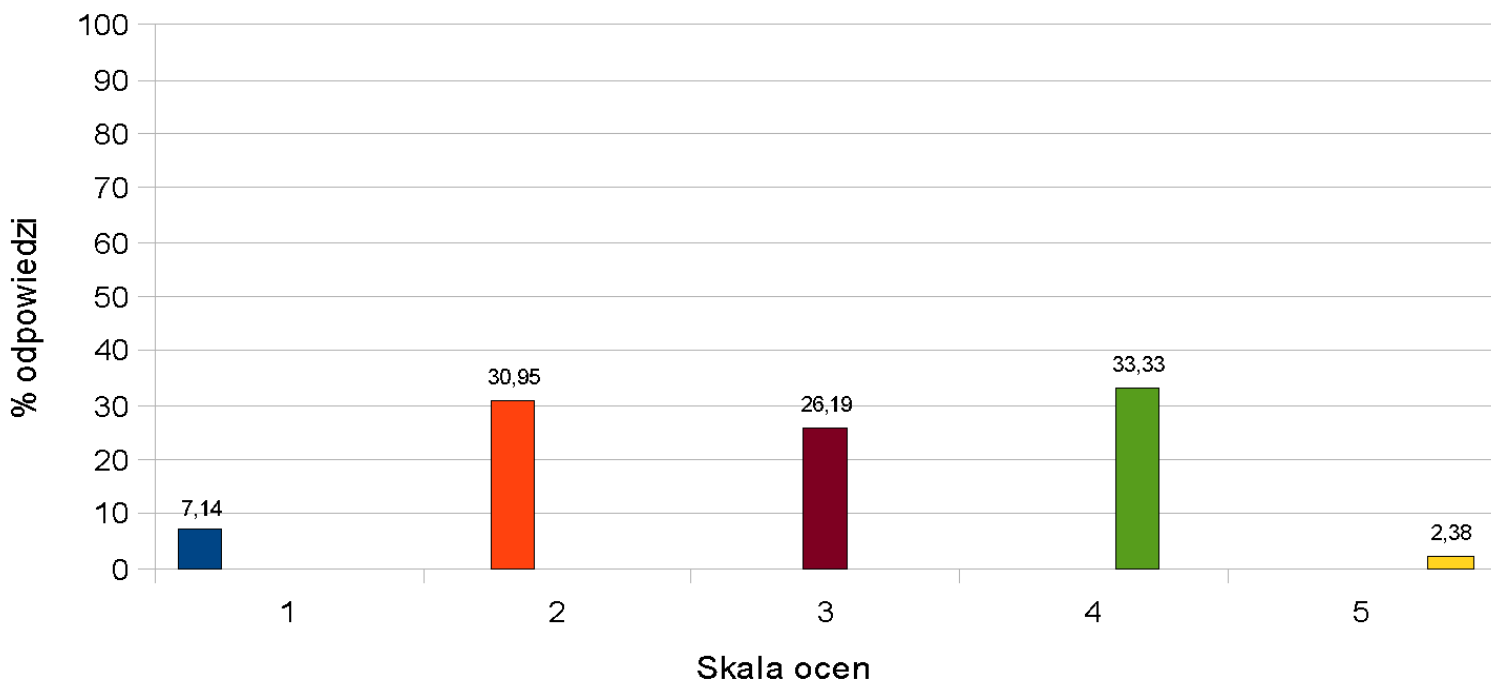

Wykres 1. Ocena poziomu komunikatywności

Źródło: Opracowanie na podstawie przeprowadzonych badań

W kolejnym pytaniu poproszono ankietowanych pracowników Poczty Polskiej o wyrażenie opinii na temat efektywności komunikacji w przedsiębiorstwie. Jest to następny krok w dążeniu do weryfikacji hipotezy badawczej dotyczącej wpływu komunikacji na realizację celów organizacji. Aby ocenić poziom komunikacji w przedsiębiorstwie, należy wziąć pod uwagę nie tylko jakość relacji z klientami, ale również relacje zachodzące wewnątrz przedsiębiorstwa.

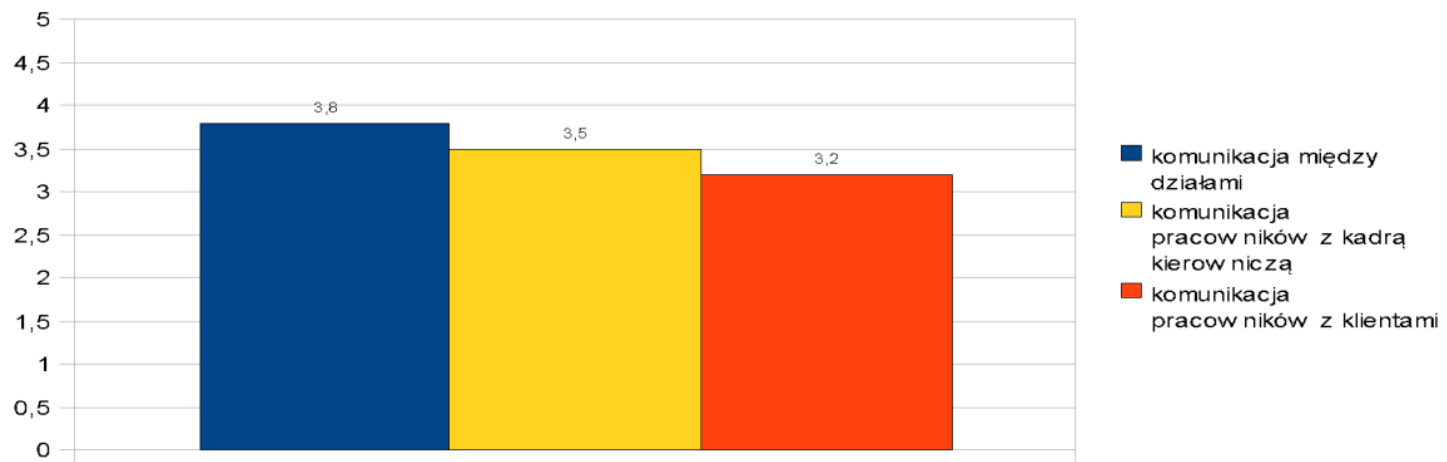

Wykres 2. Średnie oceny komunikacji

Źródło: Opracowanie na podstawie przeprowadzonych badań 
Ankietowani najwyżej oceniają komunikację między działami, a za najmniej efektywne uznają relacje z klientami. Wszystkie oceny przekraczają nieco średni poziom. Wyniki nie są zbyt imponujące, co pozwala sądzić, że pracownicy zdają sobie sprawę z niedoskonałości procesów komunikacyjnych w przedsiębiorstwie. Taki stan rzeczy stanowi dobrą podstawę do podniesienia efektywności komunikacji przez wprowadzenie szeregu zmian w tym zakresie. Zmiany te podjęte być powinny $\mathrm{z}$ wcześniejszym uświadomieniem sobie istniejących niedociągnięć.

Podsumowując powyższe badania, można zauważyć niedoskonały proces komunikacyjny między pracownikami a klientami, bowiem najniższa ocena dotyczy właśnie tego rodzaju komunikacji, co nie najlepiej świadczy o tej organizacji.

6. Ocena skuteczności procesu komunikowania na sprawność działania organizacji

Termin organizacja pochodzi od łacińskiego słowa „organum”, oznaczającego pierwotnie narzędzie, a następnie narząd, czyli część organizmu żywego. Organizm złożony jest $z$ powiązanych i ściśle współpracujących ze sobą narządów ( organów), realizujących swoje specyficzne funkcje, ale tworzących jednak zwartą całość podporządkowaną wspólnemu celowi. Tego typu analogie zaważyły na współczesnych sposobach rozumienia organizacji.

Poczta Polska działa jak jeden wielki „organizm”, którego poszczególne „,narządy” przeznaczone są do wykonywania określonych zadań. Niestety usterka jednego z tych „narządów” powoduje opóźnienie działania, lub co gorsza całkowite jego zatrzymanie. Skuteczność funkcjonowania Poczty Polskiej (tak jak innych organizacji) zależy od wielu czynników, spośród których kluczową rolę odgrywa czynnik ludzki, tworzący organizację i decydujący o jej sukcesie. Istotę stanowi komunikacja pomiędzy pracownikami, a także komunikowanie się z kierownictwem organizacji.

Klientom Poczty i jej pracownikom zadane zostało pytanie, czy według nich istnieje zależność pomiędzy jakością świadczonych usług, a poziomem komunikacji (tabela 3 ).

Tabela 3

Umiejętności komunikacyjne a jakość ustug

\begin{tabular}{|l|c|c|c|c|}
\hline \multirow{2}{*}{ Odpowiedzi } & \multicolumn{2}{|c|}{ Klienci } & \multicolumn{2}{c|}{ Pracownicy } \\
\cline { 2 - 5 } & Liczność & $\%$ & Liczność & Procent \\
\hline Tak & 35 & 83 & 36 & 90 \\
\hline Nie & 3 & 7 & 4 & 11 \\
\hline Trudno Powiedzieć & 4 & 12 & 5 & 9 \\
\hline
\end{tabular}

Źródlo: Opracowanie na podstawie przeprowadzonych badań

Odpowiedzi respondentów na to pytanie potwierdziły słuszność przypuszczeń, że klienci wiążą jakość wykonywanych przez Pocztę usług z umiejętnościami komunikacyjnymi pracowników. Aż 83\% ankietowanych zdecydowanie dostrzega tę zależność. Znaczny odsetek klientów ocenia też wpływ komunikowania się na zadowolenie z usług.

Również pracownicy odpowiadali na to pytanie bardzo podobnie. Oni również uważają, że umiejętności komunikacyjne decydują o jakości usług.

Poczta Polska organizuje wiele szkoleń mających na celu podniesienie jakości procesu komunikowania się. Szkolenia te przełożyć się mają na sukces przedsiębiorstwa usługowego. Choć jest to bardzo czasochłonne zadanie, warto poświęcić mu uwagę, gdyż z dużym prawdopodobieństwem przyniesie znaczne korzyści w przyszłości, powodując wyższy poziom realizacji celów tej organizacji.

7. Bariery procesu komunikowania

Bariery komunikacyjne mogą tkwić zarówno po stronie nadawcy jak i odbiorcy, ale mogą też wynikać z różnych poziomów wiedzy, jak również z odmiennego postrzegania i oceniania określonej sytuacji. Bariery komunikacyjne mogą mieć różny charakter ( tabela 4 ).

Tabela 4

Charakter powstawania barier komunikacyjnych

\begin{tabular}{|c|c|}
\hline Charakter powstałych barier & Uwarunkowania \\
\hline Fizyczny & Związany z warunkami, w których proces się odbywa \\
\hline Organizacyjny & $\begin{array}{r}\text { Dotyczy struktury przedsiębiorstwa, oraz pozycji zajmowanej przez } \\
\text { uczestników procesu w hierarchii }\end{array}$ \\
\hline Psychologiczny & $\begin{array}{l}\text { Znacznie głębszy i trudniejszy do niwelowania, uwarunkowany } \\
\text { różnicami osobowościowymi ludzi biorących udział w procesie }\end{array}$ \\
\hline
\end{tabular}

Źródło: Opracowanie na podstawie: Potocki A., Komunikacja wewnętrzna w przedsiębiorstwie, Wydawnictwo Akademii Ekonomicznej w Krakowie, Kraków 2001, ss.18-19 
Bariery fizyczne to warunki zewnętrzne, takie jak nieodpowiednia temperatura, nadmierny hałas itp. Pojawienie się tego typu barier jest niezależne od uczestników interakcji. W odniesieniu do badanego Urzędu Pocztowego taką barierą jest mała przestrzeń, nadmierny hałas i odbieranie komunikatów skierowanych do innych osób, co nie pozwala rozmówcom na skupienie uwagi i powoduje dyskomfort. Bariery organizacyjne zależne są od stanowiska zajmowanego w organizacji, jak również od sposobu wykonywania pracy na poszczególnych stanowiskach, podziału obowiązku i zadań. Bywa, że pełna informacja dociera tylko do niektórych stanowisk, podczas gdy inne, $\mathrm{z}$ racji usytuowania na niższym szczeblu hierarchii, otrzymują tę samą informację w znacznie okrojonym zakresie. Bariery psychologiczne to przeszkody trudne do usunięcia z powodu indywidualnych cech osobowości człowieka, wielorakiej natury ludzkiej oraz różnic w interpretacji przekazywanych komunikatów.

Kierując się własnymi doświadczeniami oraz głęboko zakorzenionymi stereotypami, często odrzuca się stanowisko rozmówcy, nie podejmując wysiłku zrozumienia i spojrzenia na komunikat przez pryzmat rozmówcy. Relacje międzyludzkie „generowane są przez osobę, którą codziennie oglądamy w lustrze”"22 Podobnie jest $\mathrm{z}$ efektywną komunikacją. Biorąc udział w procesie komunikacji, należy starać się zrozumieć rozmówcę i spojrzeć na sprawę z jego perspektywy. Ten sposób pozwala zbliżyć się do komunikacji doskonałej.

Bariery komunikacyjne występują zarówno na gruncie prywatnym, jak i na płaszczyźnie organizacji, gdzie efektywna komunikacja stanowi podstawę w budowaniu trwałych więzi, dających fundament w kształtowaniu wysokiego poziomu satysfakcji zawodowej pracowników, dążeniu do wspólnego celu i osiągania sukcesu. Dlatego tak istotna jest umiejętność przewidywania potencjalnych, możliwych do wystąpienia barier, bądź rozpoznanie już istniejących, a następnie podejmowanie próby ich skutecznego przezwyciężania. Negatywne nastawienie do odbiorców komunikatu i stawiania ich na przegranej pozycji bardzo często powoduje powstawanie barier komunikacyjnych i znacznie ogranicza możliwości utworzenia więzi między członkami procesu komunikacyjnego.

Bariery komunikacyjne wzrastają wraz z wielkością organizacji. W małych organizacjach zatrudnieni mają możliwość stałego kontaktu ze sobą, co znacząco sprzyja integracji. Problem nasila się wraz ze zwiększoną ilością zatrudnionych. Im większa liczba zatrudnionych, tym bardziej utrudnione kontakty przełożonych z podwładnymi. Kierownicy, często słabo przeszkoleni w zakresie skutecznej komunikacji, nie próbują nadać procesom porozumiewania się określonych norm, ale pozostawiają je własnemu biegowi, co wprowadza chaos i dezorientację wśród pracowników. ${ }^{23}$ Komunikacja jest często zatrzymywana lub zniekształcana na którymś ze szczebli hierarchii organizacyjnej, dlatego należy wypracować taki system przekazywania informacji, który pozwoli na skuteczne komunikowanie się pracowników. ${ }^{24}$

Tabela 5 przedstawia istotne bariery komunikacyjne w organizacji, z uwzględnieniem przyczyn ich powstawania. Trudno jest przewidzieć zachowanie ludzkie w określonych okolicznościach. Należy więc dążyć do ciągłego doskonalenia umiejętności komunikacyjnych i szukać odpowiednich metod, które pozwolą sprawnie funkcjonować w organizacjach.

W celu sprawnego funkcjonowania organizacji należy poznać, które z barier odgrywają największą rolę w komunikowaniu się, powodując tym samym błędne odczytywanie informacji i podjąć działania likwidujące te bariery.

8. Propozycje zmian w obszarze komunikowania w organizacji

Sukces działania organizacji publicznych, w tym także Poczty Polskiej w dużej mierze uzależniony jest od wysokiego poziomu procesu komunikowania się zarówno wewnątrz, jak i na zewnątrz organizacji. Występujące w organizacji bariery prawidłowej wymiany informacji wpływają negatywnie na wizerunek przedsiębiorstwa. Duże znaczenie mają tu zdolności komunikacyjne pracowników. To oni decydują jak postrzegana jest firma. Z tego powodu, istotne znaczenie ma wdrażanie rozwiązań przeciwdziałających nieprawidłowemu procesowi komunikacji.

Aby znaleźć i zaproponować skuteczne metody, zwalczające istniejące bariery i usprawniające komunikację w badanej instytucji, należy uwzględnić tu ocenę klientów dotyczącą sfery komunikacyjnej. Wdrożenie zmian może stać się szansą na poprawę poziomu zadowolenia z pracy pracowników oraz pozwoli na wzrost poziomu satysfakcji klientów Poczty Polskiej ze świadczonych przez nią usług.

Zmianie powinna ulec zarówno komunikacja zewnętrzna pomiędzy pracownikami a klientami, jak również komunikowanie wewnątrz przedsiębiorstwa. Pracownicy są świadomi istoty komunikacji, co można uznać za podstawę wdrożenia usprawnień w tym zakresie. Pierwszy krok, to prowadzenie intensywnych szkoleń i treningów, dzięki którym pracownicy będą mogli pogłębiać swoją wiedzę i umiejętności komunikacyjne, nauczyć się panować nad negatywnymi emocjami, przezwyciężać konflikty. Szczególny nacisk należy postawić na wdrożenie szkoleń z zakresu komunikowania.

\footnotetext{
${ }^{22}$ Adair J. Anatomia biznesu - komunikacja, wyd. EMKA, Warszawa 2000, s. 37

${ }^{23}$ Ibidem, s. 54

${ }^{24}$ Stankiewicz J., Komunikowanie... op.cit. ss. $137-140$
} 
Bariery komunikacyjne w organizacji

\begin{tabular}{|c|c|c|}
\hline $\begin{array}{l}\text { Przyczyna } \\
\text { powstania } \\
\text { bariery }\end{array}$ & Rodzaj bariery & Opis \\
\hline \multirow[t]{5}{*}{ Nadawca } & $\begin{array}{l}\text { Przeładowanie } \\
\text { informacyjne }\end{array}$ & $\begin{array}{l}\text { Brak możliwości zapamiętania nadmiernej liczby informacji przez } \\
\text { odbiorcę, możliwość pominięcia najistotniejszych treści przekazu w } \\
\text { powstałym chaosie informacyjnym }\end{array}$ \\
\hline & $\begin{array}{l}\text { Brak obiektywizmu w } \\
\text { przekazywaniu } \\
\text { informacji }\end{array}$ & $\begin{array}{l}\text { Zbyt jednostronne przedstawianie sprawy. Uwypuklanie własnego } \\
\text { punktu widzenia, próba jego narzucenia odbiorcom }\end{array}$ \\
\hline & $\begin{array}{lr}\text { Nier r uwzlędnianie } \\
\text { możliwości odbiorców }\end{array}$ & $\begin{array}{l}\text { Używanie niezrozumiałych słów, zbyt szybkie przekazywanie } \\
\text { informacji, brak empatii }\end{array}$ \\
\hline & Emocje & $\begin{array}{l}\text { Niepohamowanie gniewu, zdenerwowania nadmiernego entuzjazmu czy } \\
\text { innych emocji, nadmierna krytyka wobec rozmówców }\end{array}$ \\
\hline & $\begin{array}{l}\text { Wysyłanie } \\
\text { sprzecznych sygnałów }\end{array}$ & $\begin{array}{l}\text { Niespójność między komunikacją werbalną i niewerbalną, powodująca } \\
\text { dezorientację odbiorcy }\end{array}$ \\
\hline \multirow[t]{3}{*}{ Odbiorca } & $\begin{array}{l}\text { Brak zaufania do } \\
\text { nadawcy }\end{array}$ & $\begin{array}{l}\text { Negatywne informacje pozyskane wcześniej dotyczące nadawcy, } \\
\text { niejasne intencje, z góry przesądzają o negatywnym nastawieniu, } \\
\text { skazując proces komunikacyjny na niepowodzenie }\end{array}$ \\
\hline & $\begin{array}{l}\text { Błędna interpretacja, } \\
\text { treści przekazu }\end{array}$ & $\begin{array}{l}\text { Doszukiwanie się treści, których w rzeczywistości przekaz nie zawiera, } \\
\text { bądź odbieranie treści zgodnie z wcześniejszym nastawieniem }\end{array}$ \\
\hline & $\begin{array}{l}\text { Przedwczesna } \\
\text { interpretacja, błędne } \\
\text { motywy }\end{array}$ & $\begin{array}{l}\text { Na podstawie szczątkowych, nie do końca wysłuchanych, czy } \\
\text { odczytywanych informacji, odbiorca usiłuje zgadywać jakie są intencje } \\
\text { nadawcy }\end{array}$ \\
\hline
\end{tabular}

Źródto: Opracowanie na podstawie: J. Stankiewicz, Komunikowania się w organizacji, Astrum, Wrocław 1999, s.137-140

Niezbędnym elementem zmian jest usprawnienie przebiegu informacji wewnątrz przedsiębiorstwa i określenie jednolitych, jasnych kanałów komunikacyjnych, które pozwolą na likwidację chaosu informacyjnego związanego z dublowaniem się poleceń oraz wielokrotnym przekazywaniem tych samych informacji zwrotnych. Kolejna zmiana powinna dotyczyć większego zaangażowania pracowników niskich szczebli zarządzania w tworzenie nowych rozwiązań i umożliwienie im samodzielnego podejmowania wielu decyzji. Należy zrobić wszystko, aby skutecznie konkurować i pozostać na czołowej pozycji tej branży. Nie można tego dokonać bez profesjonalnej kadry, świadomej znaczenia umiejętności komunikacyjnych w świadczeniu usług. Warto więc mobilizować pracowników do doskonalenia umiejętności komunikacyjnych, które znajdą odzwierciedlenie w wysokim poziomie satysfakcji zawodowej, a tym samym staną się podstawą do osiągnięcia sukcesu.

Podsumowanie. Urząd Pocztowy jako instytucja o charakterze publicznym, posiada cechy odpowiadające wszystkim rodzajom organizacji. Wyróżnia się jednak posiadanym systemem celów i wartości oraz specyfiką więzi wewnątrzorganizacyjnych. Posiada zróżnicowane grupy interesariuszy zewnętrznych i z tego powodu tak dużą rolę w realizacji celów organizacji na wysokim poziomie spełnia tu komunikacja. Komunikacja jest zjawiskiem złożonym i w każdej zorganizowanej całości pełni istotną rolę. Stanowi podstawę procesu zarządzania - to za jej pośrednictwem menedżerowie w jednostkach publicznych planują, organizują, motywują i kontrolują. Z drugiej strony, tylko dzięki odpowiednio zorganizowanemu procesowi komunikowania się $\mathrm{z}$ otoczeniem możliwe jest pozyskiwanie rzetelnych i dokładnych informacji - niezbędnych do podejmowania prawidłowych decyzji w organizacji. Wyniki przeprowadzonych badań pozwalają jednoznacznie stwierdzić, że organizacja procesu komunikowania się w instytucjach publicznych bezpośrednio wpływa na poziom sprawności ich działania. Poziom komunikacji w Poczcie Polskiej można uważać za przeciętny. Pracownicy powinni zwrócić większą uwagę na poprawę jakości komunikowania zarówno wewnątrz firmy jak i w relacji z klientami. Należy postawić na wysoki poziom kompetencji na poziomie komunikacyjnym. Komunikacja wiąże się z poczuciem dobrze spełnionego obowiązku, satysfakcją, a co za tym idzie z sukcesem zawodowym. Zdolności komunikacyjne budują pozytywny wizerunek, a doskonalenie komunikowania jako specyficznego obszaru funkcjonowania organizacji wpłynie pozytywnie na sprawność jej działania. 


\section{Bibliografia:}

1. Adair J. Anatomia biznesu - komunikacja / J.Adair. - Warszawa : EMKA, 2000.

2. Griffin R.W. Podstawy zarządzania organizacjami / R.W. Griffin. - Warszawa : Naukowe PWN, 2004.

3. Hogan K. Psychologia perswazji. Strategie i techniki wywierania wpływu na ludzi / K.Hogan. - Warszawa : Jacek Santorski \& Co, 2001.

4. Izdebski M. Administracja publiczna - zagadnienia ogólne / M.Izdebski, M.Kulesza. - Warszawa : Liber, 2004.

5. Kożuch B. Podstawy zarządzania organizacjami / B.Kożuch, A.Kożuch, B.Plawgo. - Kraków : FWZ, 2005.

6. Kożuch B. Zarządzanie publiczne w teorii i praktyce polskich organizacji / B.Kożuch. - Warszawa, 2004.

7. Listwan T. Zarządzanie kadrami / T.Listwan. - Warszawa : C.H. Beck, 2004.

8. Ekonomika i zarządzanie małą firmą / in B.Piasecki red. - Łódź : PWN, 2001.

9. Plawgo B. Zarządzanie relacjami organizacji publicznych z ich otoczeniem / B.Plawgo, A.Szpak, P.Radziwon ; in B.Kożuch red. // Problemy zarządzania organizacjami publicznymi, Kraków, 2006.

10. Sobkowiak B. Współczesne systemy komunikowania / B.Sobkowiak. - Wrocław : Wydawnictwo Uniwersytetu Wrocławskiego, 1998.

11. Stankiewicz J. Komunikowanie się w organizacji / J.Stankiewicz. - Wrocław : Astrum, 1999. - Pp. 38.

12. http://www.poczta-polska.pl/historia.

\section{References:}

1. Adair, J. (2000), Anatomia biznesu - komunikacja, EMKA, Warszawa.

2. Griffin, R.W. (2004), Podstawy zarzadzania organizacjami, Naukowe PWN, Warszawa.

3. Hogan, K. (2001), Psychologia perswazji. Strategie i techniki wywierania wplywu na ludzi, Jacek Santorski \& Co, Warszawa.

4. Izdebski, M. and Kulesza, M. (2004), Administracja publiczna - zagadnienia ogólne, Liber, Warszawa.

5. Kożuch, B., Kożuch, A. and Plawgo, B. (2005), Podstawy zarządzania organizacjami, FWZ, Kraków.

6. Kożuch, B. (2004), Zarządzanie publiczne w teorii i praktyce polskich organizacji, Warszawa.

7. Listwan, T. (2004), Zarzadzanie kadrami, C.H. Beck, Warszawa.

8. Piasecki, B. (ed.) (2001), Ekonomika i zarządzanie mała firma, PWN, Łódź.

9. Plawgo, B., Szpak, A. and Radziwon, P. (2006), «Zarządzanie relacjami organizacji publicznych z ich otoczeniem», in Kożuch, B. (ed.), Problemy zarządzania organizacjami publicznymi, Kraków.

10. Sobkowiak, B. (1998), Współczesne systemy komunikowania, Wydawnictwo Uniwersytetu Wrocławskiego, Wrocław.

11. Stankiewicz, J. (1999), Komunikowanie się w organizacji, Astrum, Wrocław, pp. 38.

12. http://www.poczta-polska.pl/historia

KONIUSZ Maria - dr Wyższa Szkoła Ekonomiczno-Humanistyczna Bielsko Biała Polska 